DOI: 10.31577/ahs-2019-0020.01.0008

ACTA HYDROLOGICA SLOVACA

Ročník 20, č. 1, 2019, 74 - 79

\title{
SOIL MOISTURE CHANGES AFTER BIOCHAR APPLICATION IN 2018
}

\author{
Justína Vitková, Peter Šurda
}

\begin{abstract}
Biochar, a product of thermal degradation of biomass, helps to improve the hydrophysical properties of the soil. It works at soils with low quality primarily but its use in conventional agricultural temperate soils has often different effect and depends mainly on the material from which the biochar is produced, the process of pyrolysis, the soil to which the biochar is applied and last but not least, the cultivated crop. In this paper, we deal with changes in silt-loam soil moisture at plots with applied biochar in amount of $20 \mathrm{t} / \mathrm{ha}$ and at plots without biochar in 2018. The cultivated crop was spring barley (Hordeum vulgare L.) during the monitoring period June-July 2018. Soil moisture was measured by 5TM sensors. The results confirmed the conclusions of a number of scientific studies that soil moisture was higher at plots with biochar at about 3-8\% vol. than at plots without biochar application.
\end{abstract}

KEY WORDS: biochar, soil moisture, spring barley

ZMENY VLHKOSTI PÔDY PO APLIKÁCII BIOUHLIA V ROKU 2018. Použitie biouhlia, produktu termálnej degradácie biomasy, napomáha zlepšovat' hydrofyzikálne vlastnosti pôdy. Primárne však vlastnosti pôd s nízkou kvalitou, preto jeho použitie $\mathrm{v}$ bežných pol’nohospodárskych pôdach mierneho pásma má často rozdielne účinky a závisí predovšetkým od materiálu, z ktorého je biouhlie vyrobené, od procesu samotnej pyrolýzy, od pôdy do akej sa biouhlie aplikuje a v neposlednom rade od pestovanej plodiny. V tomto príspevku sa venujeme zmenám vo vlhkosti prachovito hlinitej pôdy na plochách s aplikovaným biouhlím a bez aplikácie biouhlia v roku 2018. Počas monitorovacieho obdobia jún - júl 2018 bol pestovanou plodinou jačmeň jarný (Hordeum vulgare L.). Vlhkost' pôdy bola meraná pomocou senzorov 5TM. Výsledky potvrdili závery viacerých odborných štúdií, že na plochách s biouhlím bola vlhkost' pôdy vyššia o $3-8 \%$ obj. oproti plochám bez biouhlia.

KLÚČCVÉ SLOVÁ: biouhlie, vlhkost' pôdy, jačmeň jarný

\section{Úvod}

Soil water is part of the hydrosphere located in soil profile and, together with groundwater and surface water, is the third source of water that is directly involved not only in the hydrological but also in the production and biological cycle. This water source has not an alternative to the crop production process and it is sensitive not only to climate change but also to anthropogenic activities (Demo et al., 2000). Changes in land use and the country's total water balance affect runoff processes and soil moisture (Rončák et al., 2016; 2017). Soil moisture is one of the basic elements the total water balance. It can be affected by surface runoff, soil erosion, infiltration processes or land management (Danáčová et al., 2017). Biochar, as a product of carbon-rich thermal degradation of biomass, can improve soil hydrophysical properties, increase crop yields, improve soil quality and nutrient cycle, as well as stimulate soil microbial activity. The microscopic physical structure of biochar is one of the key determinants in its soil properties. The specific surface area of the pre-charred source material can be increased several thousand fold (Beesley and Marmiroli, 2011). This increased surface area is the result of the thermal decomposition of the organic material through which the volatiles are conducted and the remainning structure consists of highly concentrated carbon chains (Lehmann and Joseph, 2009). The most well-known example of using biochar for agricultural purposes is the Terra Preta land from the pre-Columbian times in the Amazon River basin. These soils were created by adding large amounts of charcoal to the soil to increase the nutrients of the poor 
rainforest lands (Taylor, 2010). Many scientific studies have dealt with the impact of applied biochar on soil properties. Conclusions suggest that the use of biochar primarily helps low quality soil, so its use in conventional agricultural temperate soils often has different effects and depends primarily on the feedstock material, the pyrolysis process, and the amount of applied biochar. A substantial part of the research works was focused on sandy soils that are more prone to the consequences of reduced organic material. The results confirm that biochar can increase water retention in sandy soils (Bruun et al., 2014; Abel et al., 2013; Uzoma et al., 2011; Brockhoff et al., 2010). These studies conclude that the biochar application is generally a benefit for a soil and its hydrophysical properties. Ulyett et al. (2014) dealt with different land management practices. Ultimately, they concluded that the use of biochar increased water retention regardless of whether the land was farmed in a conventional or organic manner. The results of research in Slovakia confirmed the increase of soil $\mathrm{pH}$ after biochar application (Horák, 2015), improvement of soil sorption properties (Šimanský and Horák, 2017), but also the density of soil enhanced by the combination with compost (Rodný et al., 2017). By using a modern and simple technique, whose methodology was described by Kondrlová et al. (2017), there is possible to track changes in plant growth during the growing period, to detect differences in crop yields and to spread weeds at plots with and without applied biochar. Vitková et al. (2017) described connection between crop yields and soil moisture after biochar application. Crop yields were higher at plots with higher soil moisture regardless of whether there was biochar or not.

In this paper, we focused on assessing the impact of applied biochar on soil moisture in field conditions during monitoring period in 2018. There is not too much research studies in Slovakia about impact of biochar on soil moisture with different types of vegetation. That's why we continue with our research which started in 2015.

\section{Material and methods}

Our measurements were conducted at the experimental site in Malanta (Fig. 1), which belongs to the Slovak University of Agriculture in Nitra. The research site is located approximately $5 \mathrm{~km}$ north-east of Nitra city (N48 19'00"; E18 $\left.09^{\prime} 00^{\prime \prime}\right)$ in the Nitra river basin, where there is a deficit of soil water available to plants due to dry years (Tárník and Leitmanová, 2017). The locality is $175 \mathrm{~m}$ above sea level and the soil is classified as a siltloam with content of sand $15.2 \%$, silt $59.9 \%$ and clay 24.9\% (Šimanský and Klimaj, 2017). Biochar, we used for our research, was applied to the soil in March 2014. A more detailed specification of the experiment foundation was described by Vitková and Šurda (2016). Basic biochar characteristics of used biochar are shown in Table 1. The biochar was produced from paper fiber sludge and grain husks in a ratio of 1:1 per weight, at a pyrolysis temperature of $550^{\circ} \mathrm{C}$ (Domanová et al., 2015). We focused on two plots with a maximum of

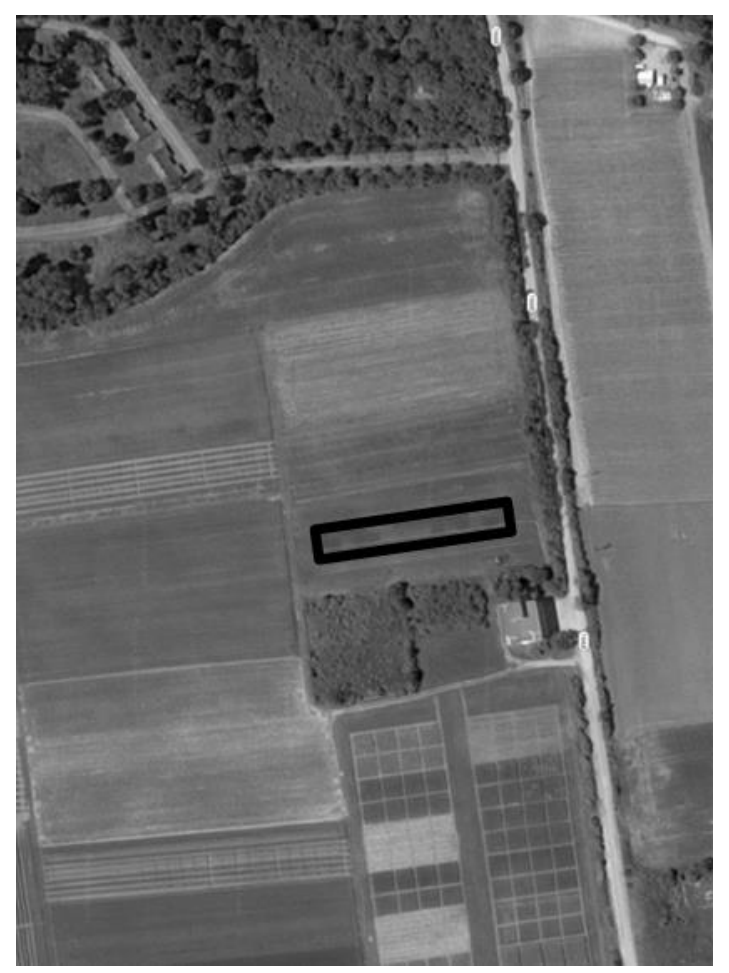

Fig. 1. The experimental site localization ( Google maps 2019).

Obr. 1. Lokalizácia výskumnej lokality (C Google maps 2019). 
applied biochar, i.e. 20 t.ha $^{-1}$ (B20) and their comparison with two non-biochar plots (Kontrola). Two sensors were installed at each plot in a distance of about $30 \mathrm{~cm}$ from each other. The correlation coefficient between measured soil moistures at one plot was 0.86 or 0.92 , respectively. Therefore we used the arithmetic mean of all sensors at the B20 plots and the arithmetic mean of all sensors at the Kontrola plots for more detailed analysis. Soil moisture was measured using the 5TM dielectric sensors by Decagon Devices (USA) and data was collected in five-minute interval and stored using the EM 50 data loggers. The monitoring period lasted from 22.06.2018 to 24.07.2018. The sensors were installed at a depth of 5$10 \mathrm{~cm}$ below the soil surface. The spring barley (Hordeum vulgare L.) was grown at the experimental site during the vegetation period in 2018 .

\section{Results and discussion}

Our measurements from 2018 showed that higher soil moisture at B20 plot was measured in comparison to the Kontrola plot in about 3-8\% vol. during monitoring period (Fig. 2). The difference between B20 and Kontrola plots increased statistically insignificant during the longer non-precipitation period (30.06.-05.07., or 13.17.07.). In general, the monitoring period (as well as the vegetation period) was very dry and the year 2018 was the warmest or equally warmest in the history of measurements in the meteorological station Nitra Janíkovce according to SHMÚ (2019). The range of measured soil moistures is shown at Fig. 3. Difference between average values at B20 and Kontrola plots was $5 \%$ vol. Regression analysis revealed a positive relationship between the measured soil moisture values at B20 and Kontrola plots (Fig. 4). The Pearson correlation coefficient, dealing with the dependence between soil moisture at B20 and Kontrola plots, was r $=0.93$, indicates a strong dependence between variables. The measured soil moisture confirmed the conclusions of several scientific studies about increasing soil retention capacity after biochar application into the soil. Our previous research about impact of biochar on soil moisture which started at the same locality and at the same research plots in 2015 did not confirm directly that the applied biochar has a positive effect on soil moisture at studied area. In 2015, when the maize was grown, soil moisture in the Kontrola

Table 1. Biochar characteristics

Tabul'ka 1. Zloženie biouhlia

\begin{tabular}{|c|c|c|c|c|c|c|c|}
\hline \multirow{4}{*}{ Biochar } & $\begin{array}{c}\mathbf{C} \\
{[\%]}\end{array}$ & $\begin{array}{c}\mathbf{N} \\
{[\%]}\end{array}$ & $\begin{array}{c}\mathbf{H} \\
{[\%]}\end{array}$ & $\begin{array}{c}\mathbf{O} \\
{[\%]}\end{array}$ & $\begin{array}{c}\mathbf{p H}\left(\mathrm{CaCl}_{2}\right) \\
{[-]}\end{array}$ & $\begin{array}{c}\mathbf{A s h} \\
{[\%]}\end{array}$ & $\begin{array}{c}\text { SSA } \\
{\left[\mathrm{m}^{2} . \mathrm{g}^{-1}\right]}\end{array}$ \\
\cline { 2 - 8 } & 53.1 & 1.4 & 1.84 & 5.3 & 8.8 & 38.3 & 21.7 \\
\hline
\end{tabular}

$\mathrm{C}$ - carbon, $\mathrm{N}$ - nitrogen, $\mathrm{H}$ - hydrogen, $\mathrm{O}$ - oxygen, $\mathrm{pH}$ determined by $\mathrm{CaCl}_{2}$, $\mathrm{SSA}$ - specific surface area

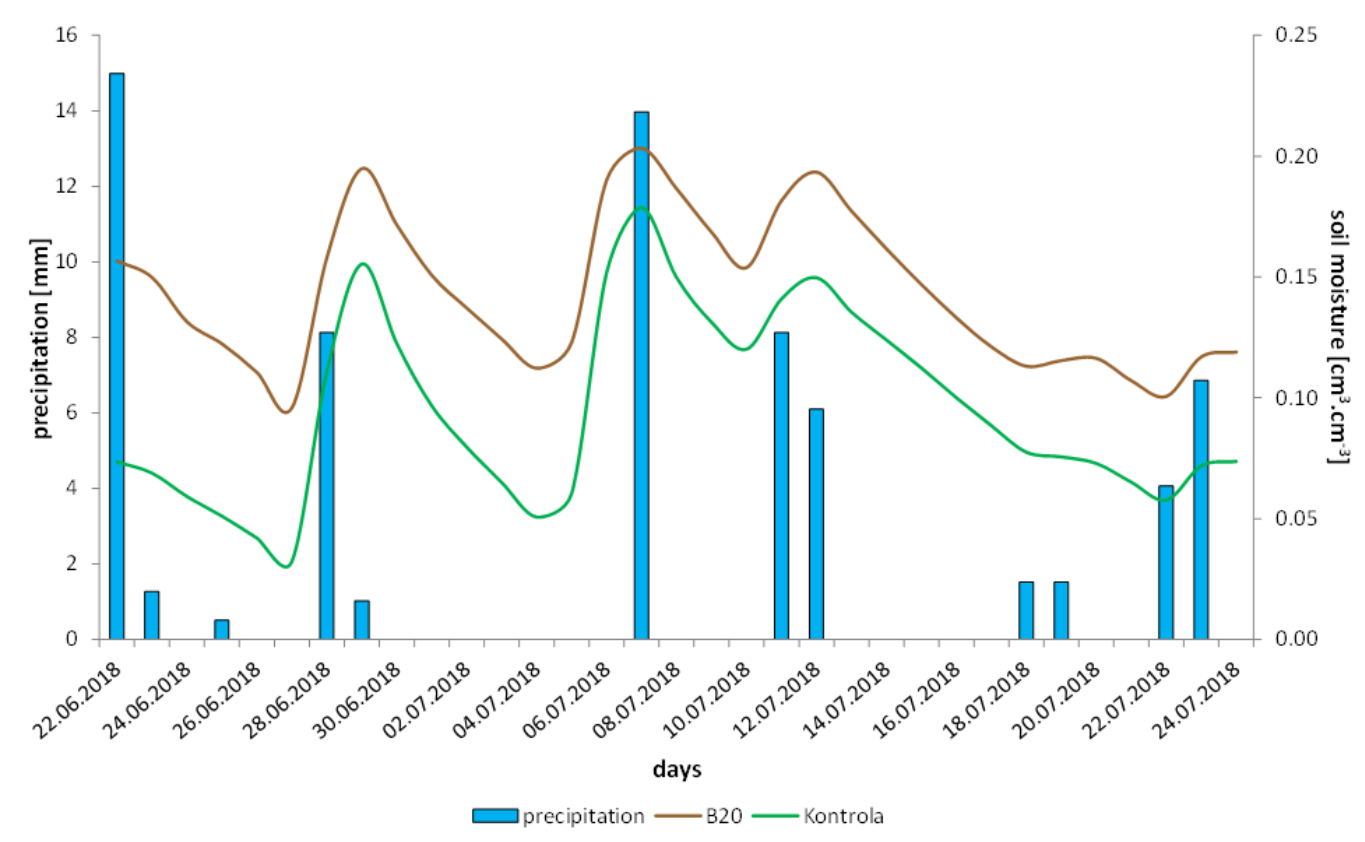

Fig. 2. $\quad$ Measured soil moisture at plots with biochar application (B20) and without biochar (Kontrola) in comparison to daily precipitation totals during monitoring period.

Obr. 2. Namerané vlhkosti pôdy na plochách s aplikovaným biouhlím (B20) a na plochách bez biouhlia (Kontrola) v porovnanís dennými úhrnmi zrážok počas monitorovaného obdobia. 


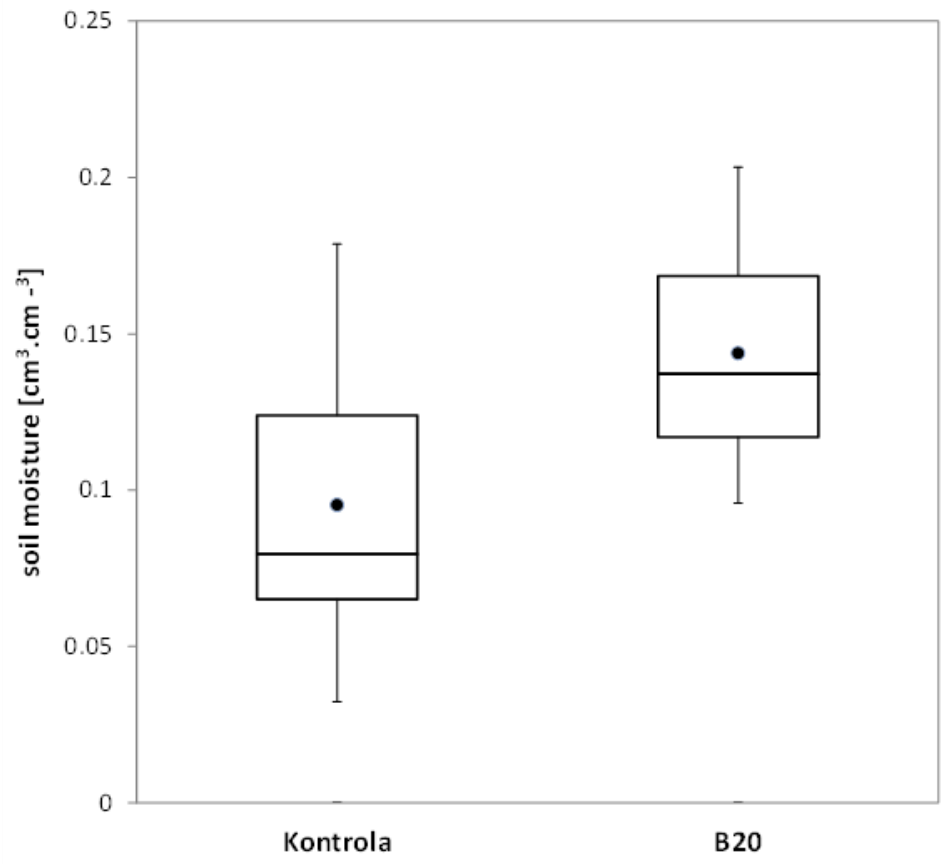

Fig. 3. Measured soil moisture at Kontrola and B20 plots during monitoring period. Value range: minimum, $25^{\text {th }}$ percentile, median, $75^{\text {th }}$ percentile, maximum and circles represent average value.

Obr. 3. Namerané vlhkosti pôdy na plochách Kontrola a B20 počas monitorovaného obdobia. Rozsah hodnôt: minimum, 25 percentil, medián, 75 percentil, maximum a čierny krúžok predstavuje priemernú hodnotu.

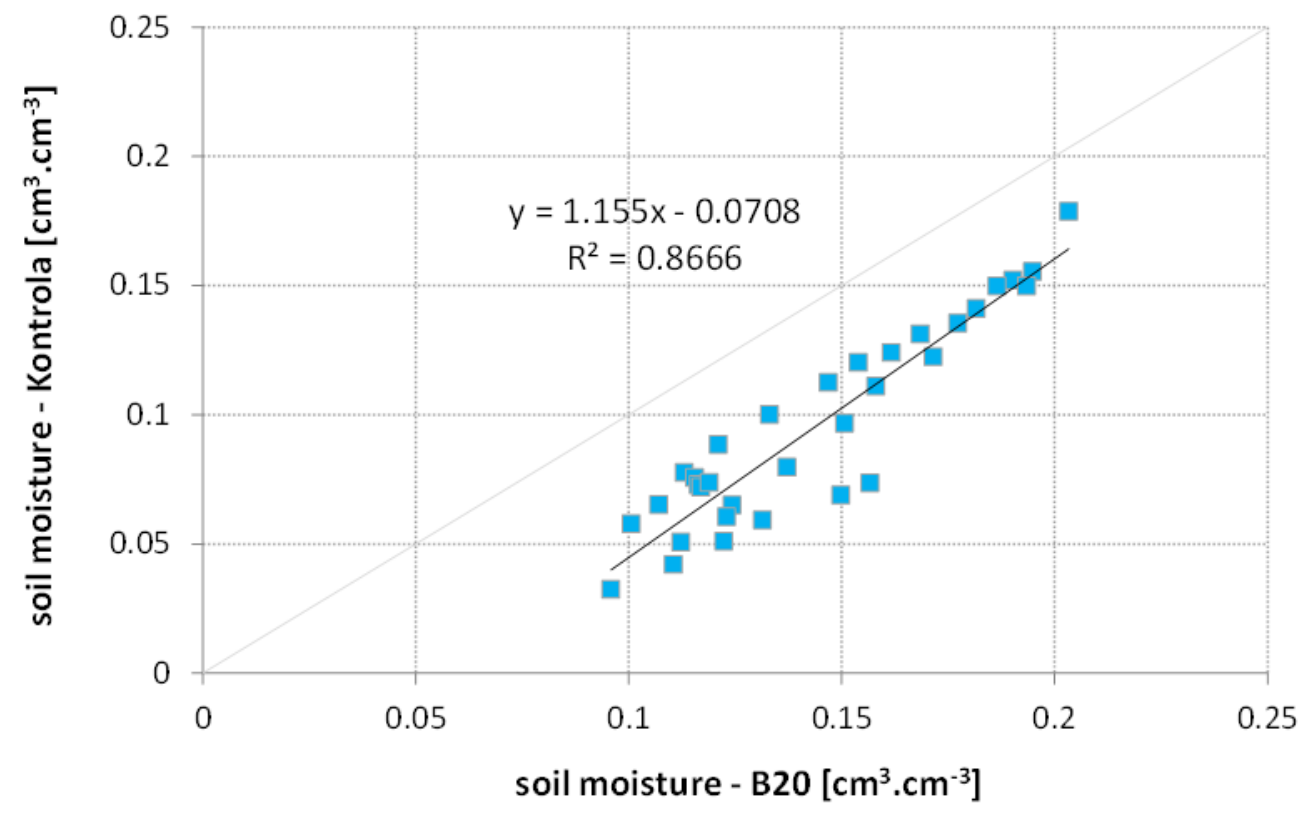

Fig. 4. Linear regression of dependence between measured soil moisture at Kontrola and B20 plots.

Obr. 4. Lineárna regresia závislosti nameraných vlhkostí pôdy na plochách Kontrola a B2O. 
plot was higher than at B20 plot during the monitoring period and in 2016, when spring wheat was grown, there was higher soil moisture at Kontrola plot but after more intensive precipitation events the soil moisture was higher at B20 plot (Vitková et al., 2017). In 2018, when the spring barley was grown, the soil moisture was higher at B20 plot than Kontrola plot during the whole monitoring period. It should be added that biochar was applied to the soil in 2014 and since that time it is naturally degraded, it becomes a part of soil aggregates and thus its properties change. This may also be one of the reasons why the results of our measurements were different.

\section{Conclusion}

In this paper, we have focused on impact of applied biochar on soil moisture in field conditions during monitoring period in 2018. We have continued in our previous research at Malanta area, where biochar with the above mentioned properties was applied to the silt-loam soil in March 2014. Soil moisture was measured since 2015 with the same 5TM sensors. Differences between studied years were in cultivated crops and meteorological conditions, which cannot be influenced by human. Therefore it was possible to assess the impact of biochar on soil moisture under various climatic and vegetation conditions. The results of 2015 and 2016 did not always show the positive effect of applied biochar on soil moisture. The opposite results were found in 2018, when root system of spring barley positively reacted on this type of biochar, and it is therefore advisable to apply it to silt-loam soil to increase its moisture and retention capacity. In conditions of the ongoing climate change, when there is needed to retain water in the country, the results of our measurements are very hopeful. However, we need to verify our results to confirm these conclusions. But based on our results we can say that the cultivated crop directly affects the effect of biochar added to the soil in field conditions.

\section{Acknowledgement}

This work was supported by Scientific Grant Agency No. VEGA 2/0053/18 and is also the result of the project implementation ITMS 26210120009 Infrastructure completion of hydrological research stations, supported by the Research \& Development Operational Programme funded by the ERDF.

\section{Literature}

Abel, S., Peters, A., Trinks, S., Schonsky, H., Facklam, M., Wessolek, G. (2013): Impact of biochar and hydrochar addition on water retention and water repellency of sandy soil. Geoderma, Vol. 202, 183-191.

Beesley, L., Marmiroli, M. (2011): The immobilisation and retention of soluble arsenic, cadmium and zinc by biochar. Environ Pollut, Vol. 159, No. 2, 474-480.
Brockhoff, S.R., Christians, N.E., Killorn, R.J., Horton, R., Davis, D.D. (2010): Physical and mineral-nutrition properties of sand-based turfgrass root zones amended with biochar. Agron. Journal, Vol. 102, 1627-1631.

Bruun, E. W., Petersen, C. T., Hansen, E., Holm, J. K., Hauggaard-Nielsen, H. (2014): Biochar amendment to coarse sandy subsoil improves root growth and increases water retention. Soil Use and Management, Vol. 30, No. 1, 109-118.

Danáčová, M., Výleta, R., Valent, P., Hlavčová, K. (2017): The impact of slope gradients on the generation of surface runoff in laboratory conditions. In $17^{\text {th }}$ International Multidisciplinary Scientific GeoConference SGEM 2017, Hydrology and Water Resources, Vol. 17, 677-684.

Demo, M., Bielek, P., Húska, D., Jureková, Z., Kostrej, A., Hraška, S., Antal, J., Cagáň, L., Rehák, S., Dlouhý, J. (2000): Regulatory technologies in the production process of agricultural crops. Nitra : Slovak University of Agriculture, SR, 648 .

Domanová, J., Igaz, D., Borza, T., Horák, J. (2015): Retenčné charakteristiky pôdy po aplikácii biouhlia. Acta Hydrologica Slovaca, Vol. 16, No. 2, 193-198.

Horák, J. (2015): Testing biochar as a possible way to ameliorate slightly acidic soil at the research field located in the Danubian lowland. Acta Horticulturae et Regiotecturae, Vol. 18, No. 1, 20-24.

Kondrlová, E., Horák, J., Igaz, D., Dobiašová, D. (2017): The possibility of using digital images in assessment of plant canopy development and weed spread. Acta Horticulturae et Regiotecturae, Vol. 20, No. 2, 35-39.

Lehmann, J., Joseph, S. (2009): Biochar for Environmental Management: Science and Technology. London: Earthscan/James \& James, UK, 450.

Rodný, M., Vitková, J., Šurda, P., Igaz, D., Horák, J., Domanová, J., Borza, T. (2017): Vplyv biouhlia, kompostu a anorganického hnojenia na využitel'nú vodnú kapacitu a objemovú hmotnost' piesočnatohlinitej pôdy. Acta Hydrol. Slovaca, Vol. 18, No. 1, 98-103.

Rončák, P., Hlavčová, K., Látková, T. (2016): Estimation of the Effect of Changes in Forest Associations on Runoff Processes in Basins: Case Study in the Hron and Topl'a River Basins. Slovak Journal of Civil Engineering, Vol. 24, No. 3, 1-7.

Rončák, P., Lisovszki, E., Szolgay, J., Hlavčová, K., Kohnová, S., Csoma, R., Poorová, J. (2017): The potential for land use change to reduce flood risk in mid-sized catchments in the Myjava region of Slovakia. In Contributions of Geophysics and Geodesy, Vol. 47, No. 2, 95-112.

SHMÚ, (2019): 2018 - najteplejší rok na viacerých miestach Slovenska. cit. [2019-03-29]. Dostupné na: <http:// www.shmu.sk/sk/?page $=2049 \&$ id=972>

Šimanský V., Klimaj A. (2017): How does biochar and biochar with nitrogen fertilization influence soil reaction? Journal of Ecological Engineering, Vol. 18, $50-54$.

Šimanský, V., Horák, J . (2017): Pôdna reakcia a parameter sorpčného komplexu po aplikácii biouhlia a biouhlia s dusikatým hnojením. Agrochémia, Vol. 2, 20-24.

Tárník, A., Leitmanová, M. (2017): Analysis of the Development of Available Soil Water Storage in the Nitra River Catchment. In IOP Conference Series: Materials 
Science and Engineering, WMCAUS, 245, art No. 062017.

Taylor, P. (2010): The Biochar Revolution: Transforming Agriculture \& Environment. Mt Evelyn Victoria: Global Publishing Group, Australia, 377.

Ulyett, J., Sakrabani, R., Kibblewhite, M., Hann, M. (2014): Impact of biochar addition on water retention, nitrification and carbon dioxide evolution from two sandy loam soils. European Journal of Soil Science, Vol. 65, No. 1, 96-104.

Uzoma, K.C., Inoue, M., Andry, H., Zahoor, A., Nishihara, E.
(2011): Influence of biochar application on sandy soil hydraulic properties and nutrient retention. Journal of Food, Agriculture \& Environment, Vol. 9, 1137-1143.

Vitková, J., Kondrlová, E., Rodný, M., Šurda, P., Horák, J. (2017): Analysis of soil water content and crop yield after biochar application in field conditions. Plant Soil and Environment, Vol. 63, No. 12, 569-573.

Vitková, J., Šurda, P. (2016): Vplyv aplikácie biouhlia na vlhkost' v povrchovej vrstve pôdy. Acta Hydrologica Slovaca, Vol. 17, No. 2, 287-292.

\section{ZMENY VLHKOSTI PÔDY PO APLIKÁCII BIOUHLIA V ROKU 2018}

V našom predchádzajúcom výskume sme sa zamerali na vplyv aplikovaného biouhlia, s vy̌š̌ie spomenutými vlastnost'ami, na vlhkost' pôdy v pol'ných podmienkach. Od roku 2015 sme merali vlhkost' pôdy na výskumnej lokalite Malanta, pričom rozdiely medzi jednotlivými rokmi boli v pestovanej plodine a meteorologických podmienkach, ktoré sa nedajú ovplyvnit' činnost'ou človeka. Preto bolo možné posúdit' vplyv biouhlia na vlhkost' pôdy za rôznych klimatických a vegetačných podmienok. Výsledky z rokov 2015 a 2016 nevykazovali vždy pozitívny efekt tohto biouhlia na vlhkost' pôdy. Opak nastal až pri meraniach v roku 2018, kedy môžeme konštatovat', že koreňový systém jačmeňa jarného reagoval pozitívne na tento typ biouhlia. Je preto vhodné ho aplikovat' pri pestovaní jačmeňa do prachovito hlinitej pôdy na zvýšenie jej vlhkosti a retenčnej schopnosti. V podmienkach prebiehajúcej klimatickej zmeny, kedy je potreba zadržiavat' vodu v krajine, je výsledok našich meraní vel'mi nádejný. Je však potrebné urobit' verifikáciu našich výsledkov na potvrdenie týchto záverov. S určitost'ou však môžeme konštatovat', že pestovaná plodina priamo vplýva na efekt biouhlia pridaného do pôdy.

Ing. Justína Vitková, PhD.

Ing. Peter Šurda, PhD.

Ústav hydrológie SAV

Dúbravská cesta 9

84104 Bratislava

Tel.: $\quad$ +421232293519

E-mail: vitkova@uh.savba.sk

surda@uh.savba.sk 